\title{
GENESIS OF SPIRITUAL EDUCATION IN UKRAINE: HISTORICAL BACKGROUND
}

\section{Yuliia Shulha}

\section{INTRODUCTION}

In the XX century our country experienced significant changes in the public-political structure and social life: from Russian Empire, UPR, Ukrainian state to the USSR, finishing XX century within the borders of the proclaimed on August 24, 1991 the newly created state - Ukraine. But perhaps there were no periods in our country that so sorely needed strengthening of their spiritual foundations, and never before was so clearly defined the task of preserving its traditions and culture. The complex processes taking place in our country nowadays, are not only socioeconomic but also spiritual and moral by its nature. Of particular relevance in this context is the issue of education of future generations.

Today the citizens of Ukraine are interested in updating approaches and principles of upbringing and education, as they life in a qualitatively changed conditions of life. The modern family is often focused on wealth, not on moral education of younger generation. In this regard, the importance of time-tested social institutions and their activities for preservation and cultivation of social values is proved. These institutions include the Christian church, which, among other objectives, aims at preserving traditions of spiritual education. In this context tradition is considered not only as a repetition of usual forms of educational process but also as creation of new forms and methods of upbringing and spiritual education of relevant content and values.

The problem of spirituality has always been relevant, inexhaustible and occupied an important place in various fields of scientific knowledge. Prominent philosophers, psychologists, educators dedicated many studies to this subject. Today, one of the main ways of forming spiritual personality is spiritual education. Spiritual education has a positive effect on the overall morality of Ukrainian society, based on the Orthodox Christian moral. Therefore, the study of spiritual education development in Ukraine is relevant.

\section{Origination of educational processes in the period of Kievan Rus}

The education system in Ukraine has ben formed with penetration and spread of Christianity. In historical, philosophical, religious, educational and 
other works the process of development of spiritual education in Ukraine is revealed, the positive role of Christianity in the spread of education and culture on Ukrainian lands is stressed. Along with introduction of Christianity and organization of Church starts formation of education institutions. According to the researcher of church history P. Znamensky, "education in Rus was initiated simultaneously with introduction of Christianity, which awakened the first need in book learning Rus community, brought first books with it"1.

Spiritual aspirations to find the true path and opportunities of salvation formed the basis of education and corresponed to the the Christian worldview. Church consciousness that was formed based on the teachings of the Church Fathers, "considered theology not as a rational science, but as a science and practical knowledge of God, that at the same time requires for its realization a deep study of faith and the experience of the Fathers"2. This gives reason to believe that education was not aimed at comprehending the greatest volume of theological knowledge, but only those of them that were necessary for salvation in the Cross. That is the main purpose of education was the sanctity of life and theoretical knowledge that contributed to the spiritual and moral formation of the person, was considered the means of achieving this goal. So, "major efforts of ancient Rus pedagogy were focused on helping people acquire the Christian virtues and compare their affairs and thoughts with Christian morality that was true wisdom, as opposed to purely cognitive wisdom that is not reinforced by actions and deeds" 3

Christian culture "required new training system aimed at adapting to the literacy necessary for mastering the Christian doctrine and worship celebration"4. Christian knowledge spread in Slavic environment through the liturgy and clergy's preaching activities.

\footnotetext{
${ }^{1}$ Znamenskij, P. V. (2000). Istoriya russkoj cerkvi [History of Russian Church]. Narodnoe obrazovanie v trudah istorikov russkoj cerkvi: Hrestomatiya, ss. 34-48. Vladivostok: Izdatelstvo Dalnevostochnogo universiteta (in Russian).

${ }^{2}$ Osipov, A. (2003). Po obrazu Hrista: o duhovnom obrazovanii v RPC [In the image of Christ: about spiritual education in the Russian Orthodox Church]. Pravoslavnaya beseda, 2, 7-11 (in Russian).

3 Doroshenko, Yu. I. (2000). Hristianstvo $i$ russkoe nacionalnoe obrazovanie. Pravoslavnaya pedagogika: tradicii $i$ sovremennost [Orthodox pedagogy: traditions and modernity. Collection of lectures and reports]. Sbornik lekcij i dokladov, ss. 83-94. Vladimir: VGPU (in Russian).

${ }^{4}$ Dneprov, E. D. (Red.) (1989). Ocherki istorii shkoly i pedagogicheskoj mysli narodov SSSR $s$ drevnejshih vremen do konca XVII v. [Essays on the history of school and pedagogical thought of the peoples of the USSR from ancient times to the end of the 17th century]. M.: Pedagogika (in Russian).
} 
Development of education is closely linked with development of writing. I. Vlasovskyi emphasizes the importance of book that became the basis of Christian education. "The new faith - he said - that was aimed at providing new Christian worldview and bring up people in the Christian morality had influence not only through the service available to the masses, but also through Christian literature, although the circle of readers was very limited at that time" $"$. It has become a significant factor in spreading education and science among the Slavic peoples and Ukrainian in particular.

In the scientific community the role of Cyril and Methodius in the history and culture of the Ukrainian people was highly appreciated. In the opinion of I Vlasovskyi, they sowed the seeds of Christian education in Slavic language and East Orthodox spirit for further religious, moral, cultural-educational and artistic development of each of the Slavic peoples ${ }^{6}$. Salonika brothers, having become one of the first preachers gave rise to formation of sources of theological literature and education. In addition to valuable books for Slavic world, they brought up their students. We can assume that individual teaching Russians literacy began not with opening of schools by princes or priests, but with emergence of the first Greek preachers. Thus, even before the adoption of Christianity in Kievan Rus there were literate people who created the foundation for the spread of education, and became the first teachers of Christian world.

Qualitatively new stage of the education system development in the eastern Slavs became Prince Vladimir activities aimed at creating a network of schools. The first Christian prince by making a formal baptism of Rus, began to open schools and forcibly take away children in "Book learning". Chronicles texts give evidence of weeping mothers who sent their children to school like to death. Therefore studies show that in the initial stages of its development, the school was perceived as a dangerous innovation, that could destroy ancient traditions ${ }^{7}$.

Besides education needed for public use, the princes paid more attention to decent clergy training, because the spread of Christianity in the Slavic world was one of the main tasks. Domestic researchers suggest that in the

\footnotetext{
${ }^{5}$ Vlasovskyi, I. (1955). Narys istorii Ukrainskoi Pravoslavnoi Tserkvy [An outline of the history of the Ukrainian Orthodox Church]. Tom 1. Niu-York. Repr. Vyd. Kyiv, 1998. P. 70. (in Ukrainian).

${ }^{6}$ Vlasovskyi, I. (1955). Narys istorii Ukrainskoi Pravoslavnoi Tserkvy [An outline of the history of the Ukrainian Orthodox Church]. Tom 1. Niu-York. Repr. Vyd. Kyiv, 1998. P. 60. (in Ukrainian).

${ }^{7}$ Dneprov, E. D. (Red.) (1989). Ocherki istorii shkoly i pedagogicheskoj mysli narodov SSSR $s$ drevnejshih vremen do konca XVII $v$. [Essays on the history of school and pedagogical thought of the peoples of the USSR from ancient times to the end of the 17th century]. M.: Pedagogika. P. 28 (in Russian).
} 
early stages of Christianization priests were enough only for urban parishes, so organized within episcopal chairs were organized primary schools to train clergy of Russian origin. Education of parish clergy was low, so by the larger churches were monks who were considered not only educated, but also holy ${ }^{8}$.

Firstly, state promoted the spread of Christianity and creation of schools, and with strengthening of Old Russian church organization these functions were completely given to the latter. The church became the centre of national education and upbringing, and educated priests give basic knowledge to the masses in the light of Christian teaching. Teaching children was provided at elementary literacy schools that existed in churches and parishes. "Pastors of the church and ancient scribes were constantly trying to convince everyone about the importance of "Book learning" and great value of the divine books both for salvation and mortal life" .

In schools for priests and members of the clergy training was aimed at acquiring reading and writing skills, church singing skills, obligatory was mastering of the basics of Christian faith and morals. Having got the basics of reading and writing, the priest could continue training, but for this were capable only a few. The basis of such training laid pastors' literary science. The ability to read books and their understanding was considered a way to salvation. Thus, central to the educational system was the work with the text as the main source of basic Christian morality. Further studies were usually based on self-education and mastery of the Greek language and study other, except religious, literature. Formation of Christian literacy skills was a professional challenge of priesthood. Book learning, that coexisted with a simple study of grammar, was regarded as a holy and pious and considered the higher level of education.

It becomes clear that the Church had almost a monopoly on public awareness. Exploring the history of the Orthodox Church in Kievan Rus, I. Vlasovskyi notes: “...whatever was the goal of "Book learning" in those days - either practical training of clergy (and government officials) or more theoretical - raising education level of the upper strata - still, education of

\footnotetext{
${ }^{8}$ Kolodnyi, A. (Red.) (1997). Istoriia relihii v Ukraini [History of religion in Ukraine]: U 10 t. T.2: Ukrainske pravoslavia. Kyiv. P. 116 (in Ukrainian).

${ }^{9}$ Znamenskij, P. V. (2000). Istoriya russkoj cerkvi [History of Russian Church]. Narodnoe obrazovanie v trudah istorikov russkoj cerkvi: Hrestomatiya, ss. 34-48. Vladivostok: Izdatelstvo Dalnevostochnogo universiteta (in Russian).
} 
that time in content and nature, was imbued with religious and Church spirit" $"$.

Christianity necessitated learning, because new religion had to give not only a new Christian worldview, but also to educate people on the basis of Christian morality. Education and training was conducted through the service, which was available to the masses, and clergy was considered most educated people. Over time, there is a gradual spread of schools in all cities of Kievan Rus. Taking into account the needs of the Church, education was spreading. The church was the main teacher of both clergy and ordinary population, using all possible forms and methods for mastering the basic tenets of the Christian faith.

Particularly important role in the development of education played monasteries. With specific climate of holistic upbringing, they became major education institutions. In addition to individual training and education of monks, monasteries had a great moral influence on society. In such an environment, which theory was closely intertwined with practice, formed science. In the monastery originates Russian bookishness. Studying in the annals of the universal experience of the saints and getting proper guidance of Christian life, the stratum of educated monks who were the educational base of Kievan Rus was gradually growing. Here the best books were copied and translated that "taught a person, not corrupted him under the pretext of education... Such literature laid the foundation for education in Rus, which had brought the highest spiritual fruit in XIV-XV centurie" $"$.

Adjustments in religious and educational life made various historical events. Particularly notable changes occurred as a result of the Mongol invasion, when traditional education institutions were destroyed. For a long time training and educational traditions were interrupted, leading to loss of principal value of some education institutions and creation of others. According to the team of scientists, only "after the Mongol invasion in Russia gradually formed a kind of education system, genetically linked with traditions of Kievan Rus, which had significant differences from both Western and Byzantine education system..."12. Although the monasteries

${ }^{10}$ Vlasovskyi, I. (1955). Narys istorii Ukrainskoi Pravoslavnoi Tserkvy [An outline of the history of the Ukrainian Orthodox Church]. Tom 1. Niu-York. Repr. Vyd. Kyiv, 1998. P. 72 (in Ukrainian).

${ }^{11}$ Osipov, A. (2003). Po obrazu Hrista: o duhovnom obrazovanii v RPC [In the image of Christ: about spiritual education in the Russian Orthodox Church]. Pravoslavnaya beseda, 2, 7-11 (in Russian).

${ }_{12}$ Dneprov, E. D. (Red.) (1989). Ocherki istorii shkoly i pedagogicheskoj mysli narodov SSSR $s$ drevnejshih vremen do konca XVII $v$. [Essays on the history of school and pedagogical thought of the peoples of the USSR from ancient times to the end of the 17th century]. M.: Pedagogika (in Russian). 
were destroyed, which were the main centers of training and education, books as the main source of knowledge were ruined, educated people no longer performed their basic functions - accumulation and transfer of knowledge, the educational process was interrupted, we cannot talk about general educational decline. Education remained in the same form. Its foundation constituted traditional schools operating in churches and monasteries.

\section{Development of theological education}

\section{in the Ukrainian lands in the XIV-XVII century}

Development of education in Galicia-Volyn Principality and later in Lithuanian- Ruthenian state continued. At the initial stages the education system was characterized by one-sidedness, reflected in its focus on the outer side of religious life. "Code of information, feelings and skills that were considered essential for mastering these rules constituted the science on "Christian life", on how Christians should live... Orthodox theology limited the role of reason in matters of faith, believing that knowledge of God was possible through intuition, feeling, moral heroism ..." ${ }^{\text {13 }}$. Such education from time to time met the needs of the Church and the state in educated people.

Professional education of clergy that emerged already at the early stages of Christianity, was working on a book. For ordinary people the book was inaccessible, and therefore the main source of knowledge remained Christian cult. Church worship and rites spread among the people religious imagery and met cognitive needs concerning upbringing of piety and Christian morality. Such content of education showed that in Ukrainian lands the Church, unlike in the West, had not separate theological education, it didn't establish schools similar to European. Fulfilling the main task of education preparing teachers of God's Word and affirming people in the Christian faith, the Church did not streamline educational process and could not form a coherent and stable school system.

Fundamentals of primary education for a long time satisfied the Church in dissemination of education and Christian morality. However, lack of special secondary schools and higher education resulted in the necessity to get education in the West, where highly educated individuals were trained who met the needs of the time. With Orthodox religious ceremony, the clergy and the upper strata of society established close relations with the Western Catholic Europe in education. Later historical events in the West

13 Dneprov, E. D. (Red.) (1989). Ocherki istorii shkoly i pedagogicheskoj mysli narodov SSSR $s$ drevnejshih vremen do konca XVII v. [Essays on the history of school and pedagogical thought of the peoples of the USSR from ancient times to the end of the 17th century]. M.: Pedagogika. P. 41-42 (in Russian). 
quite clearly affected development of education in the Orthodox world. Reformation in Western Europe caused a qualitative change in the religious environment and education in particular. Lublin Union and joining Ukrainian lands to Poland led to the spread of Catholic and Protestant educational ideas and norms. This religious situation for a long time was reflected in the interplay of different faiths educational traditions. Educational tradition of Kievan Rus intertwined with the educational achievements of Latin Europe. "Ukrainian culture preserved spiritual roots of the East Slavic unity while actively mastered the achievements of Western education, transformer and transmitter of which was Poland"14.

An important achievement of Protestantism was set up and widespread introduction of school affairs. Protestant education institutions, like Catholic and Orthodox, performed preaching and educational tasks. At the same time V. A. Liubashchenko considers "an important sign of Protestant schools in the XVI century that distinguished them from many religious education institutions, was a special presence of secular principles: new-faith school were created not as narrow theological institutions, but were directed primarily at education widely educated, versatile person, ready to participate in political and cultural life" $" 15$. Education, which provided Protestant schools, was based on the advanced achievements of Western science and successfully combined national traditions. Trying to keep up with the times, these schools were popular among representatives of different social strata. However, deploying a broad education on the early spread of Protestantism, due to certain circumstances, they could not withstand competition with educational achievements that had become traditional for Ukraine. Taking care of education of their supporters, Protestants long had considerable success in training priests, their ranks swelling from abroad ${ }^{16}$.

The main education institutions that spread "Latin Science" became Jesuit schools. Doing main task - educating people to fight the spread of Protestant ideas, they found sympathy among the Ukrainian population. Since Lublin Union and emergence of Lithuanian-Ruthenian lands Jesuits intensified propaganda of Catholicism. Catholic and Protestant education institutions that existed in Ukraine, gave the best knowledge as opposed to

${ }^{14}$ Dneprov, E. D. (Red.) (1989). Ocherki istorii shkoly i pedagogicheskoj mysli narodov SSSR $s$ drevnejshih vremen do konca XVII $v$. [Essays on the history of school and pedagogical thought of the peoples of the USSR from ancient times to the end of the 17th century]. M.: Pedagogika. P. 266 (in Russian).

${ }^{15}$ Liubashchenko, V. (1996). Istoriia protestantyzmu v Ukraini [History of Protestantism in Ukraine]. Kurs lektsii. Kyiv. P. 130 (in Ukrainian).

${ }^{16}$ Istoriya Cerkvi [History of Church] (1999). BEE Intrnational. Luck: Hristiyanske zhittya (in Russian). 
the Orthodox. They met practical needs of the Polish-Lithuanian Commonwealth and therefore were popular among young people, especially the upper strata of society. Many graduates of these schools continued to study in Western Europe ${ }^{17}$.

Analyzing this issue, researchers often argue about positive role of the Latin school in Orthodox environment or vice versa - negative aspects of the impact on the development of religious traditions. Without going into a detailed elaboration of this issue, we can state a significant shift in the educational environment. For a long time Catholic school was an example of high level of education in Ukrainian lands. Education in the Latin school did not contribute to compulsory catholization. Returning to Orthodoxy, priests not only lost their faith, but also created a favorable climate for the development of its educational system. The most visionary clergy understood the threat to Orthodoxy, recognized the need for science education. They borrowed from the West the main educational ideas, studied the outer side of education institutions activity and created information base having acquainted with achievements of science in the Latin world ${ }^{18}$.

To the high level of education that was characteristic of priests testify the studies of historians, philosophers and theologians. Metropolitan Hilarion said that the clergy always took care of their education, they were characterized by the following features: high level of education, credibility, nationality, etc. He argued that "... Since ancient time clergy of Ukrainian Church, particularly their hierarchy had always stood out for their ostentatious education, that was generally higher than education of the secular intelligentsia and clergy of other Slavic churches"19.

Despite significant improvements, the Church for a long time could not produce its own scientific or theological system. Its main objective in organizing training was that the student learned hard the truth of the Orthodox faith grounded in Scripture, regulations of ecumenical councils and writings of Church Fathers. Schools in the initial period of their existence reached the set goal through direct acquaintance with the sources of Christian doctrine. Priesthood believed that all education was to serve theology, a strong support to deal with other religious believes, because

\footnotetext{
${ }^{17}$ Liubashchenko, V. (1996). Istoriia protestantyzmu v Ukraini [History of Protestantism in Ukraine]. Kurs lektsii. Kyiv. P. 130 (in Ukrainian).

18 Golubev, S. (1886). Istoriya Kievskoj duhovnoj akademii [History of the Kiev Theological Academy]. Vip.1. Kiev. P. 176 (in Russian).

19 Moningert, G. (Red.) (1991). Obuchenie $k$ sluzheniyu. Nachalnoe obrazcovoe rukovodstvo $k$ obucheniyu uchitelya [Learning to serve. An initial model guide to teacher training]. K.: Izdatelstvo Soyuza Hristian Very Evangelskoj. P. 72 (in Russian).
} 
otherwise it was simply not useful or even harmful ${ }^{20}$. The issue of special church training organization was accidental. To combat manifestations of religious dissent and opposition from the Catholic world were needed educated priests and Orthodox theology also required scientific knowledge. The successful resolution of this problem could rectify only strong and purposeful work on organization of necessary education. In this regard, A. Pashuk notes that "... conscious and patriotic Ruthenian Ukrainian did not sit back and were aware that without education, science, knowledge Ukraine-Rus would never get out of the darkness and could not resist Polonization ${ }^{21}$.

The centre of Ukrainian religious education was Ostroh Academy. This institution put the "beginning of a real compromise between the Eastern Slavic educational traditions and "Latin science"22. It became a spiritual and religious center for the whole Ukraine and laid the foundations for the future establishment of higher education and scientific consolidation forces. According to scientists, “ $\ldots$ the importance of Ostroh Academy was not so much as an education institution, that brought up youth, but as an institute of scientists-theologians for research work, in the nature of which it was called Academy ${ }^{23}$.

Orthodox priests gradually creates schools to educate population as the most effective means in the fight against polonization and catholization. The main credit for this belongs to the fraternities. They identified development of education on the basis of Christian morality, keeping the Orthodox tradition. In the environment created by fraternities had rooted the view of science education as "the best way, leading to improvement of religious and moral values of the Orthodox Church and the proper bulwark against advancing non-Christian propaganda" 24 . Fraternities laid the foundation for the development of higher education. Establishment of education institutions in the frames of fraternal movement is particularly important in shaping

20 Golubev, S. (1886). Istoriya Kievskoj duhovnoj akademii [History of the Kiev Theological Academy]. Vip.1. Kiev. P. 205 (in Russian).

${ }^{21}$ Pashuk, A. (2003). Ukrainska tserkva i nezalezhnist Ukrainy (Ukrainian Church and Independence of Ukraine). L.: Vydavnychyi tsentr LNU im. Ivana Franka. P. 66 (in Ukrainian).

${ }_{22}$ Dneprov, E. D. (Red.) (1989). Ocherki istorii shkoly i pedagogicheskoj mysli narodov SSSR $s$ drevnejshih vremen do konca XVII $v$. [Essays on the history of school and pedagogical thought of the peoples of the USSR from ancient times to the end of the 17th century]. M.: Pedagogika. P. 271 (in Russian).

${ }^{23}$ Vlasovskyi, I. (1955). Narys istorii Ukrainskoi Pravoslavnoi Tserkvy [An outline of the history of the Ukrainian Orthodox Church]. Tom 1. Niu-York. Repr. Vyd. Kyiv, 1998. P. 233. (in Ukrainian).

${ }^{24}$ Golubev, S. (1886). Istoriya Kievskoj duhovnoj akademii [History of the Kiev Theological Academy]. Vip.1. Kiev. P. 177 (in Russian). 
religious education in Ukraine, thanks not only to the very fact of creating a national school, but the national higher education.

In 1632 by the merger of Kyiv fraternity school and school in Pechersk Monastery, founded by Petro Mohyla, appeared Kyiv Mohyla Collegium. The curriculum was designed by Petro Mohyla, whose foundation made positive achievements of Western education. The range and level of science teaching by highly educated teachers certainly suggests high status of collegium and puts it together with institutions of higher education that had already operated in Western Europe.

Playing a crucial role in the dissemination of science and education, collegium subsequently received Academy status that legalized it as an institution of higher education of Orthodox orientation, and in the XVII century, it became an important cultural center of all Ukraine. I. Ohiienko emphasizes the special place of Kyiv Academy in the history of Ukrainian culture: "Actually, this Kyiv Academy became the coal stone for our culture until the late XIX century... Students of the Academy were after graduation either priests or political leaders, highly educated" ${ }^{\prime 25}$.

Adjustments in religious life, including education development, were made by Beresteiska Church Union in 1596. Along with formation of the Greek Catholic Church appears a new school. Uniate school was defined as something unique, different from Latin and Greek Polish Slavic educational directions. Education in these schools was focused solely on the needs of Church and fulfilled the main task - training staff to strengthen the position of the Greek Catholics. Uniates formed a school that began to meet the educational needs of the population of some regions of Ukraine.

So, in Ukraine in the XIV-XVII centuries the need for development of such education that would meet the demands of society for educated personnel, various religious education institutions appeared. As in previous periods, the clergy remains the force that can shape the educational system, able to teach and educate based on Christian morality. Combining Western education with national traditions and patriotic Christian education, church gradually creates its own education system. Formation of different education institutions and, first of all, Kyiv-Mohyla Academy, that met the requirements of that time, was not only the basis of Ukrainian educational traditions, but also stimulated and prepared the basis for the development of education in other areas of Slavic peoples.

25 Moningert, G. (Red.) (1991). Obuchenie $k$ sluzheniyu. Nachalnoe obrazcovoe rukovodstvo $k$ obucheniyu uchitelya [Learning to serve. An initial model guide to teacher training]. K.: Izdatelstvo Soyuza Hristian Very Evangelskoj. P. 17 (in Russian). 
With development of education institutions the purpose of education fundamentally changes. Its basis is not the sanctity of a person, but desire to give him broad and diverse knowledge. Theological knowledge converted into the amount of knowledge instead of being a source of learning experiential knowledge of God. Teaching Christian understanding of life was replaced by the exact fulfillment of church teachings, rituals and ecclesiastical aesthetics.

With the change of the purpose of education changed also the educational process. Religious schools were formed on the example of Catholic and Protestant and adopted their system, methods, programs, textbooks that did not meet the Orthodox truths. Curriculum was expanded, classes, assessments, punishments and awards were introduced. Latin became the language of science in education institutions and an indicator of the level of education to the early XX century.

\section{Development of theological education in the XVIII - early XX century}

Historical processes, occurring in the Ukrainian territories in XVIII early XX century led to significant transformations related to redistribution of Ukrainian lands in favor of some states where preference had different denominations, led to the formation of various sectarian-oriented educational traditions.

Significant changes in education brought about transition of the Kyiv Metropolis under the jurisdiction of the Moscow Patriarchate. The clergy and secular people of Moscow state, compared with Ukraine, differed slightly in terms of education. In the schools of Moscow state were not studied general subjects, learning was based on mastering the basics of religious life, little attention was paid to people's education. In Ukraine there was an extensive educational system that tried to cover different social strata. Such education was formed due to historical events that took place in Ukrainian territory. I. Smolych gave some reasons that determined the specificity of religious education in Ukraine. First, there was schooling specifically in the spirit of the Orthodox faith, to protect children from the Catholic propaganda, and this tradition survived after the accession of Ukraine to Moscow. Second, the villages in Ukraine were well developed, which gave reasons for the favorable development of education. Also, church life developed differently than in Moscow state. Almost in each parish there was a school that was not characteristic of Moscow state ${ }^{26}$.

${ }^{26}$ Smolich, I. K. (2000). Istoriya Russkoj cerkvi [History of Russian Church]. V M. N. Kostikova (sost. i avt. vstup. st.), Narodnoe obrazovanie v trudah istorikov russkoj cerkvi: Hrestomatiya. Vladivostok: Izdatelstvo Dalnevostochnogo universiteta, ss. 152-192. S. 156 (in Russian). 
The State and the Church paid great efforts to the spread of education and religious upbrininging because they needed significant improvement. A special role in religious education played reforms of Petro I, that spread throughout the Empire and influenced the state of education in Ukraine. Before Petro's reforms there was a single education system that provided all knowledge, meeting the needs of society. After it, the school faced the task of giving such knowledge that would be useful for a change in the state. Gradually begin standing out specialized education institutions, including spiritual, oriented to priesthood training. Remaining the basic general education centers they gradually became religious education centres.

In the early 80 s of the XVIII century Russian authorities made real steps towards organization of public education. It was suggested to create schools in parishes where teachers had to be parish priests. The state attempted to control education and decided that both religious and civic education designed in a specific manner.

An example of a high level of education in Ukraine continues to be KyivMohyla collegium. Undergoing transformation and change it was until early twentieth century a theological science foundation. Collegium operated under the patronate of the Church, but theological course, which was taught there, had not been officially approved. Only in 1694 Kyiv Collegium was allowed to teach philosophy and theology courses, and since 1701 it existed as the Academy, which gave it the status of higher school. The period from late XVII century up to 1760 historians call the Era of full flowrishing of Kyiv-Mohyla Academy. Using formal independence from the Synod and following the instructions Kyiv Metropolitans, it preserved its old traditions ${ }^{27}$. Thus, Kyiv-Mohyla Academy was not a special spiritual, but a general higher school for different population groups.

In the second half of the XVIII century, Academy is going through a transition state, until it became in 1819 Kyiv Theological Academy of the Russian Orthodox Church. Ukrainian clergy and primarily outstanding figures of Kyiv Academy (Stefan Yavorskyi, Feofan Prokopovych and others) were actively involved in the development of education in the Moscow state "lifting it out of the darkness" up to the level of Ukrainian schools. A significant departure northward of scientific potential and leading role of the government in meeting the educational needs of developing society led to weakening of theological education in Ukraine. In addition, in the left-bank Ukraine in the eighteenth century were also other schools that

${ }^{27}$ Vlasovskyi, I. (1957). Narys istorii Ukrainskoi Pravoslavnoi Tserkvy [An outline of the history of the Ukrainian Orthodox Church]. Tom 3. Niu-York. Repr. Vyd. Kyiv, 1998. P. 38-40 (in Ukrainian). 
had been opened by the local Church authorities. They functioned in Chernihiv, Kharkiv, Pereiaslav, Poltava and provided local parish priesthood staff and students for Kyiv Academy. There were conditions for the formation of a system of spiritual education.

In education, there were changes directed at separation of secular schools from religious. In 1808 all religious schools were united under the supervision of the Commission of religious schools as a special spiritual and academic department. This unit was divided into academic districts where the direct supervision of the middle and lower education institutions was a duty of academies. Lower education should provide the county and parish schools, several on each parish. In seminaries that were opened in every diocese, spiritual education was provided. Academy provided higher education for graduates of the seminary and performed administrative functions. The highest course in both Academy and seminaries was theology. Academy also performed the function of a scientific center. Its graduates obtained $\mathrm{PhD}$ or master's degree, sometimes $\mathrm{DSc}$ in theology. Education in these institutions was compulsory for children of the clergy. Combining comprehensive courses and special, "in nature, all religious schools were created like class schools of a mixed type" 28 . So, gradually a single system of spiritual education for the whole empire, was introduced.

In subsequent years, content foundations of religious education institutions activity was gradually changing. Nevertheless, the general features of their work preserved until 60s of the XIX century. In the second half of the XIX century in Russia actualized economic development, formation of capitalist relations, resulting in the need to reform the education system. This led to development of new regulations for academies, seminaries, schools, defining their structure, curriculum. Management structure and relationships of the faculty, a clear division of disciplines into general and special were defined; courses of theological subjects were shortened and course of philosophy was enlarged, the study of pedagogy for training clergy to providing public education was introduced ${ }^{29}$.

As a result of reform occurs distinction between the secular and spiritual education systems. There appeared documents that defined the relationships between these systems and at the same time revealed problems in this area. According to H. Stepanenko, "Statute of 1867 had a clear division between

${ }^{28}$ Znamenskij, P. V. (2000). Istoriya russkoj cerkvi [History of Russian Church]. Narodnoe obrazovanie v trudah istorikov russkoj cerkvi: Hrestomatiya, ss. 34-48. Vladivostok: Izdatelstvo Dalnevostochnogo universiteta. P. 55 (in Russian).

${ }^{29}$ Znamenskij, P. V. (2000). Istoriya russkoj cerkvi [History of Russian Church]. Narodnoe obrazovanie v trudah istorikov russkoj cerkvi: Hrestomatiya, ss. 34-48. Vladivostok: Izdatelstvo Dalnevostochnogo universiteta. P. 55-57 (in Russian). 
general and theological education; took a big step towards destruction of clergy isolation, for clergy children it opened the opportunity to get civil higher education and, on the contrary, for secular students - get spiritual education" ${ }^{\prime 30}$.

Several departments and a large number of subjects provided education not only for preaching. Church, fulfilling important educational functions, trained personnel needed for educational work in schools of different degrees. According to the Statute, approved in 1869, religious academies faced dual purpose. H. Florovskyi emphasized that "it had to be not only a theological higher school, but also a kind of pedagogical institute of spiritual department. And academies not only prepared for the pastoral but also for teaching activities"31.

Clergy showed interest in distribution of public education. With the care of the state, priests could perform their primary task - spreading of God's Word through educational work. This activity allowed to dissiminate and enhance ideas among Orthodox youth, forming orthodox meaning of life and resisting denominational offensive. "Through educational activities Orthodox clergy widely influenced formation of the religious consciousness of their congregation, opposed, particularly Catholic and sectarian, education of youth ...."32.

At the beginning of the $\mathrm{XX}$ century religious education in Ukraine formed in all its fullness. With some problems, such education satisfied needs in education and upbringing of the population on the basis of Christian morality. Church school had noticeable advantage over secular. It remained the main primary educational element. Not being a complete monopoly of Orthodox priests and monks, primary church school held high social status ${ }^{33}$.

Theological education in the Russian empire, unlike Western countries, was provided exclusively in religious education institutions. Education institutions of other departments did not include theological faculties involved in training clergy staff. However, along with other subjects,

${ }^{30}$ Stepanenko, H. V. (2002). Osvitnia diialnist pravoslavnoho dukhovenstva $v$ Ukraini $(X I X-$ poch. $X X)$ [Educational activities of the Orthodox clergy in Ukraine (XIX - early XX)] (dys. ... kand. istor. nauk: 07.00.01). Kyiv. P. 103 (in Ukrainian).

${ }^{31}$ Florovskyi, H. V. (1983). Puty russkoho bohoslovyia [Paths of Russian theology]. 3 yzd. Repr. yzd. 1937 h. Paryzh: UMSA - PRESS. P. 51 (in Russian).

${ }^{32}$ Stepanenko, H. V. (2002). Osvitnia diialnist pravoslavnoho dukhovenstva $v$ Ukraini (XIX - poch. XX) [Educational activities of the Orthodox clergy in Ukraine (XIX - early XX)] (dys. ... kand. istor. nauk: 07.00.01). Kyiv. P. 26 (in Ukrainian).

${ }_{33}$ Nadtoka, H. M. (1998). Pravoslavna tserkva v Ukraini 1900 - 1917 rokiv: sotsialnorelihiinyi aspekt [Orthodox Church in Ukraine 1900 - 1917 Rocks: Socially Religious Aspect]. K.: Znannia. P. 207 (in Ukrainian). 
theology and church history were taught at all university faculties and it was assigned a major role in educating the younger generation ${ }^{34}$.

Theological education differed from the secular to ideological plane. There was a clear separation of secular education from theological. Such education was prerogative of the members of priests families "... church tends to increased isolation due to its transfer to the pastors' families"

The system of theological education in Ukraine, which included 41 education institution: Academy, 9 seminaries, 31 schools, was increasingly becoming dependent on the totality of religious education institutions that existed in the Russian Empire. If during previous centuries, it served as a "spiritual donor for Russia", in the early XX century it could not fully satisfy its own needs ${ }^{36}$. The church had a system of theological education and church primary schools, made a significant impact on secular education institutions, where religious disciplines were obligatory. Spiritual education, with improvements in development, reached its peak in the early XX century, but it no longer met the needs of society that was developing rapidly, and needed reforms both in religious education institutions and primary schools.

\section{CONCLUSION}

Summing up genesis of theological education in the Ukrainian lands it should be noted that with the spread of Christianity in Kievan Rus church played an important role in education of not only the clergy but also the entire population using all possible forms and techniques to master the basic tenets of the Christian faith. Simultaneously with organization of the Church began formation of education institutions. In view of its needs, education had become widespread. Church gradually streamlined the educational process and developed its own scientific theological system. Theological education of the IX-XV century was mainly dialogical in nature of communication with Christian teachers.

During the XIV-XVII centuries in Ukraine appeared various education institutions of explicitly religious orientation. The clergy left the force that was able to create an educational system and train and educate based on

\footnotetext{
${ }^{34}$ Kalnysh, Yu. (2001). Dukhovni shkoly v Ukraini: zahalnyi ohliad (Religious schools in Ukraine: general review). Liudyna i svit, 4, 32-37 (in Ukrainian).

${ }^{35}$ Nadtoka, H. M. (1998). Pravoslavna tserkva v Ukraini 1900 - 1917 rokiv: sotsialnorelihiinyi aspekt [Orthodox Church in Ukraine 1900 - 1917 Rocks: Socially Religious Aspect]. K.: Znannia. P. 37 (in Ukrainian).

${ }^{36}$ Nadtoka, H. M. (1998). Pravoslavna tserkva v Ukraini 1900 - 1917 rokiv: sotsialnorelihiinyi aspekt [Orthodox Church in Ukraine 1900 - 1917 Rocks: Socially Religious Aspect]. K.: Znannia. P. 41-42 (in Ukrainian).
} 
Christian morality. Thus, from the end of the XVI century there was a network of primary and high fraternity schools, which played a crucial role in the emergence of the first theological education institions and formation of the system of theological education in Ukrainian lands. In the XVII century religious education institutions were set up and obeyed church administration and depended mainly on the impact of the bishops, and in the XVIII century was implemented centralized management under state supervision of Holy Synod.

Reforming processes in education of the XVIII-XIX centuries led to the separation of religious schools, oriented towards training of the priesthood. Remaining basic general education centers, they gradually became centers of religious education. In education, there were changes aimed at separation of secular from religious schools and distinction between secular and spiritual education systems. Combining significant Western European teaching experience with national educational traditions and Christian education, church gradually created its own education system.

At the turn of the XIX-XX centuries spiritual education was considered the basis of educational activities that served the polity and was maintained by the government. Such education, unlike in Western countries, was provided exclusively in religious schools. In the early XX century, the Church was under the direct control of the government and any change in the system of spiritual education depended on the domestic policy of the state, but it no longer satisfied society that was developing rapidly and needed reforms.

\section{SUMMARY}

The study reveals development of spiritual education Ukraine in the historical retrospective. Research shows that development of theological education in Ukraine is a complex, long-lasting process, which began with introduction of Christianity in Ukrainian lands. Spiritual education was the most effective factor in enlightment of Ukrainian lands within their historical development until the early XX century. The stages of development of spiritual education of Ukraine are characterized. The process of spiritual education institutions development, factors and reasons that influenced their formation are analyzed. Special attention was paid to development of Kyiv Mohyla Academy as a center of theological education in Ukraine. Along with education institutions development the author traced genesis of goals of spiritual education oriented towards forming in the society of broad and diverse knowledge and influencing it. 


\section{REFERENCES}

1. Dneprov, E. D. (Red.) (1989). Ocherki istorii shkoly $i$ pedagogicheskoj mysli narodov SSSR $s$ drevnejshih vremen do konca XVII v. [Essays on the history of school and pedagogical thought of the peoples of the USSR from ancient times to the end of the 17th century]. M.: Pedagogika (in Russian).

2. Doroshenko, Yu. I. (2000). Hristianstvo $i$ russkoe nacionalnoe obrazovanie. Pravoslavnaya pedagogika: tradicii i sovremennost [Orthodox pedagogy: traditions and modernity. Collection of lectures and reports]. Sbornik lekcij i dokladov, ss. 83-94. Vladimir: VGPU (in Russian).

3. Florovskyi, H. V. (1983). Puty russkoho bohoslovyia [Paths of Russian theology]. 3 yzd. Repr. yzd. 1937 h. Paryzh: UMSA - PRESS (in Russian).

4. Golubev, S. (1886). Istoriya Kievskoj duhovnoj akademii [History of the Kiev Theological Academy]. Vip.1. Kiev (in Russian).

5. Istoriya Cerkvi [History of Church] (1999). BEE Intrnational. Luck: Hristiyanske zhittya (in Russian).

6. Kalnysh, Yu. (2001). Dukhovni shkoly v Ukraini: zahalnyi ohliad (Religious schools in Ukraine: general review). Liudyna i svit, 4, 32-37 (in Ukrainian).

7. Kolodnyi, A. (Red.) (1997). Istoriia relihii v Ukraini [History of religion in Ukraine]: $\mathrm{U} 10$ t. T.2: Ukrainske pravoslavia. Kyiv (in Ukrainian).

8. Liubashchenko, V. (1996). Istoriia protestantyzmu v Ukraini [History of Protestantism in Ukraine]. Kurs lektsii. Kyiv (in Ukrainian).

9. Moningert, G. (Red.) (1991). Obuchenie k sluzheniyu. Nachalnoe obrazcovoe rukovodstvo $k$ obucheniyu uchitelya [Learning to serve. An initial model guide to teacher training]. K.: Izdatelstvo Soyuza Hristian Very Evangelskoj (in Russian).

10. Nadtoka, H. M. (1998). Pravoslavna tserkva v Ukraini 1900 - 1917 rokiv: sotsialno-relihiinyi aspekt [Orthodox Church in Ukraine 1900 - 1917 Rocks: Socially Religious Aspect]. K.: Znannia (in Ukrainian).

11. Osipov, A. (2003). Po obrazu Hrista: o duhovnom obrazovanii v RPC [In the image of Christ: about spiritual education in the Russian Orthodox Church]. Pravoslavnaya beseda, 2, 7-11 (in Russian).

12. Pashuk, A. (2003). Ukrainska tserkva $i$ nezalezhnist Ukrainy (Ukrainian Church and Independence of Ukraine). L.: Vydavnychyi tsentr LNU im. Ivana Franka (in Ukrainian).

13. Smolich, I. K. (2000). Istoriya Russkoj cerkvi [History of Russian Church]. V M. N. Kostikova (sost. i avt. vstup. st.), Narodnoe obrazovanie v trudah istorikov russkoj cerkvi: Hrestomatiya. Vladivostok: Izdatelstvo Dalnevostochnogo universiteta, ss. 152-192 (in Russian). 
14. Stepanenko, H. V. (2002). Osvitnia diialnist pravoslavnoho dukhovenstva $v$ Ukraini (XIX - poch. XX) [Educational activities of the Orthodox clergy in Ukraine (XIX - early XX)] (dys. ... kand. istor. nauk: 07.00.01). Kyiv (in Ukrainian).

15. Vlasovskyi, I. (1955). Narys istorii Ukrainskoi Pravoslavnoi Tserkvy [An outline of the history of the Ukrainian Orthodox Church]. Tom 1. NiuYork. Repr. Vyd. Kyiv, 1998 (in Ukrainian).

16. Vlasovskyi, I. (1957). Narys istorii Ukrainskoi Pravoslavnoi Tserkvy [An outline of the history of the Ukrainian Orthodox Church]. Tom 3. NiuYork. Repr. Vyd. Kyiv, 1998 (in Ukrainian).

17.Znamenskij, P. V. (2000). Istoriya russkoj cerkvi [History of Russian Church]. Narodnoe obrazovanie $v$ trudah istorikov russkoj cerkvi: Hrestomatiya, ss. 34-48. Vladivostok: Izdatelstvo Dalnevostochnogo universiteta (in Russian).

\section{Information about the author:} Shulha Yuliia, Graduate Student

Sumy State Pedagogical University named after A.S. Makarenko 87, Romenskaya Str., 40002, Sumy, Ukraine ORCID ID: orcid.org/0000-0002-9161-1442 